\title{
A Confusing Final Diagnosis in the Differential Diagnosis of SARS-Cov-2 Associated Multisystem Inflammatory Syndrome in Children: Salmonellosis
}

\author{
Çocuklarda SARS-Cov-2 ile İlişkili Multisistem İnflamatuar Sendrom \\ Ayırıcı Tanısında Kafa Karıştıran Bir Son Tanı: Salmonelloz
}

\author{
Saliha KANIK YUKSEK' ${ }^{1}$, Belgin GULHAN¹, Gulsum Iclal BAYHAN ${ }^{1,2}$, Aslınur OZKAYA PARLAKAY1,2
}

${ }^{1}$ University of Health Sciences, Ankara City Hospital, Pediatric Infectious Diseases Department, Ankara, Turkey

1,2Yildirim Beyazit University, Faculty of Medicine, Ankara City Hospital, Pediatric Infectious Diseases Department, Ankara, Turkey

\begin{abstract}
Multisystem Inflammatory Syndrome in Children (MIS-C) is a severe clinical condition associated with the SARS-CoV-2 infection characterized by an increased inflammatory response. MIS-C shares common features with other pediatric inflammatory and infectious conditions including bacterial infections. Salmonella infections should be kept in mind as a causative agent of bacterial gastroenteritis in the differential diagnosis of patients with suspected MIS-C to avoid misdiagnosis. In this report, a case series of pediatric patients with a final diagnosis of salmonellosis were presented, although a primarily diagnosis of MIS-C at admission was considered due to symptoms and findings together with strong laboratory or epidemiological evidence for SARS-CoV-2 infection.
\end{abstract}

Key Words: Children, Misdiagnosis, Multisystem Inflammatory Syndrome, SARS-CoV-2, Salmonellosis

\section{öz}

Çocuklarda Multisistem İnflamatuar Sendrom (MIS-C), artmış inflamatuar yanıtla karakterize, SARS-CoV-2 enfeksiyonu ile ilişkili ciddi bir klinik durumdur. MIS-C, bakteriyel enfeksiyonlar dahil olmak üzere diğer pediatrik inflamatuar ve enfeksiyöz durumlarla ortak özellikler taşır. Yanlış tanıdan kaçınmak için MIS-C şüphesi olan hastalarda ayırıcı tanıda bakteriyel gastroenterit etkeni olarak Salmonella enfeksiyonları akılda tutulmalıdır. Bu raporda, SARS-CoV-2 enfeksiyonu için güçlü laboratuvar veya epidemiyolojik kanıtlarla birlikte semptomları ve bulguları nedeniyle başvuru sırasında öncelikle MIS-C tanısı düşünülmesine rağmen, kesin salmonelloz teşhisi konan pediatrik hastalardan oluşan bir vaka serisi sunulmuştur.

Anahtar Kelimeler: Çocuklar, Yanlış Teşhis, Multisistem İnflamatuar Sendrom, SARS-CoV-2, Salmonelloz

\section{INTRODUCTION}

Multisystem Inflammatory Syndrome in Children (MIS-C) is a newly reported phenomenon as a complication of severe acute respiratory syndrome coronavirus 2 (SARS-CoV-2) infection (1). This Syndrome is a more severe clinical condition than the infection itself, named as "coronavirus disease 2019 (COVID-19)", and characterized by an increased inflammatory response $(1,2)$. The pathogenesis of MIS-C is unclear, but has features overlapping with a possible autoimmune etiology and suggestive of vasculitis (1). The patients typically presents 4-6 weeks after infection with fever, multi-organ dysfunction and strongly elevated markers of inflammation, and have molecular or serological laboratory evidence of SARS-CoV-2 infection, or have a strong evidence of contact with an infected person (3). Varied clinical signs and symptoms at initial evaluation were described in MIS-C patients. Most of them have fever and gastrointestinal symptoms alone or accompanied by changes, suggestive of Kawasaki-like disease (4). The situation that makes the disease so important is cardiac dysfunction that occurs in almost half of the patients and results with shock or death (5). However, knowledge about the clinical spectrum of MIS-C remains limited, and the lack of a diagnostic test or universally (i)

0000-0002-2538-2872: KANIK YUKSEK S 0000-0003-0839-1301: GULHAN B 0000-0002-1423-4348: BAYHAN GI 0000-0001-5691-2461: OZKAYA PARLAKAY A

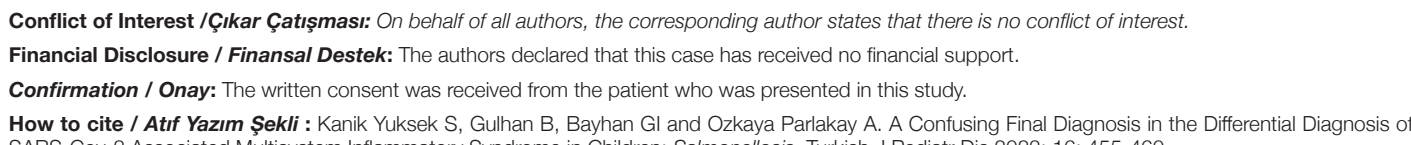

Conflict of Interest /Çıkar Çatışması: On behalf of all authors, the corresponding author states that there is no conflict of interest.

Financial Disclosure / Finansal Destek: The authors declared that this case has received no financial support. Confirmation / Onay: The written consent was received from the patient who was presented in this study.

How to cite / Atıf Yazım Şekli : Kanik Yuksek S, Gulhan B, Bayhan Gl and Ozkaya Parlakay A. A Confusing Final Diagnosis in the Differential Diagnosis of SARS-Cov-2 Associated Multisystem Inflammatory Syndrome in Children: Salmonellosis. Turkish J Pediatr Dis 2022; 16: 455-460.
Correspondence Address / Yazıșma Adresi :
Received / Geliş tarihi : : 13.07.2021 Accepted / Kabul Tarihi : 13.09.2021 Online published 07.01 .2022 Elektronik yayın tarihi

DOI: 10.12956/tchd.968975 
accepted definition makes the differential diagnosis difficult and causes it to be confused with many clinical situations $(4,5)$. Identification of MIS-C is important because timely initiation of treatment may help to correct the hyperinflammatory state, prevent end-organ damage and death (2). As MIS-C shares common features with other pediatric inflammatory and infectious conditions including bacterial infections and sepsis, the importance of differential diagnosis increases even more (1, 4). In addition, most of the MIS-C patients have gastrointestinal symptoms such as diarrhea together with fever, and of course infectious gastroenteritis with the same symptoms are frequently encountered in pediatric practice (6).

In this report, a case series of pediatric patients was presented diagnosed with salmonellosis, although a primarily diagnosis of MIS-C at admission was considered due to symptoms and findings together with strong laboratory or epidemiological evidence for SARS-CoV-2 infection.

\section{CASES REPORT}

Five children (three females, two males) aged 2.5-11.5 years who were admitted to a tertiary care hospital in the last three months of 2020 were presented in this report. All of the patients had a pre-diagnosis of MIS-C and a final diagnosis of confirmed salmonellosis. The suspicion of MIS-C was based on the case definitions established by the Centers for Disease Control and Prevention (CDC) and the World Health Organization (WHO) $(7,8)$. For all patients, symptoms and physical examination findings on admission, comorbidities, laboratory tests including blood cell counts, C-reactive protein (CRP), procalcitonin, interleukin-6, liver function tests, serum creatinine level, coagulation tests, D-dimer, ferritin, blood culture, microscopic examination and culture of stool, viral testing including reverse transcription polymerase chain reaction (RT-PCR) for SARSCoV-2 from nasopharyngeal sample, antibody testing detected lgM/lgG antibodies against SARS-CoV-2, imaging records, supportive treatments, treatments for MIS-C, antibiotherapies, and clinical outcome records were summarized separately in Table I-III.

Serovar determination was not performed on isolates obtained from any patient, since sub-species determination for Salmonella strains could not be performed in our center. Therefore, it could not be understood whether the patients had typhoid fever or invasive disease with non-typhoidal Salmonella species. Patient 4 and 5 were bacteremic supported by blood cultures. While all Salmonella strains were susceptible to ceftriaxone, ciprofloxacin and trimethoprim-sulfamethoxazole, ampicillin resistance was variable. However, clinical or laboratory response to the treatment were not obtained in patients 4 and 5 , and antibiotherapy was switched to other agents although resistance to ceftriaxone was not detected. Fever resolved in these patients after 24 hours of the treatment change. Their clinical conditions improved, and no additional treatment was applied for MIS-C.

Patient 4 was a previously healthy child with no cardiac problem. Cardiac findings detected in echocardiography returned to normal on follow-up, but 1st degree Atrioventricular (AV) block was detected before discharge in serial electrocardiograms (ECG) (shown in Table I). Arrhythmia improved without specific treatment, and 24-hour ECG monitoring was reported as normal during hospitalization. At the beginning of the process,

Table I: Demographic characteristics, symptoms / findings on admission, symptom duration, and molecular / serological laboratory or epidemiological evidence of SARS-CoV-2 infection, for all patients.

\begin{tabular}{|c|c|c|c|c|c|c|c|c|c|}
\hline Patients & Gender & $\begin{array}{c}\text { Age } \\
\text { (year) }\end{array}$ & Comorbidity & $\begin{array}{l}\text { Presenting } \\
\text { symptoms }\end{array}$ & $\begin{array}{c}\text { Symptom } \\
\text { duration } \\
\text { (day) }\end{array}$ & $\begin{array}{c}\text { Physical } \\
\text { examination } \\
\text { findings }\end{array}$ & $\begin{array}{r}\text { RT-PCR for } \\
\text { COVID-19 }\end{array}$ & $\begin{array}{c}\text { Antibodies } \\
\text { against } \\
\text { SARS-CoV-2 }\end{array}$ & $\begin{array}{c}\text { Contact with a } \\
\text { person infected } \\
\text { with COVID-19 } \\
\end{array}$ \\
\hline 1 & Female & 11.5 & Canavan disease & $\begin{array}{l}\text { Fever, diarrhea, } \\
\text { vomiting, and } \\
\text { abdominal pain }\end{array}$ & 1 & $\begin{array}{l}\text { Toxicity, } \\
\text { respiratory } \\
\text { distress, and } \\
\text { abdominal } \\
\text { tenderness }\end{array}$ & positive & non-reactive & $\begin{array}{c}+ \\
\text { (mother) }\end{array}$ \\
\hline 2 & Female & 2.5 & - & $\begin{array}{l}\text { Fever, vomiting, } \\
\text { diarrhea, and } \\
\text { abdominal pain }\end{array}$ & 3 & $\begin{array}{l}\text { Dehydration, } \\
\text { toxicity, and } \\
\text { abdominal } \\
\text { tenderness }\end{array}$ & negative & reactive & - \\
\hline 3 & Male & 7.5 & - & $\begin{array}{l}\text { Fever, vomiting, } \\
\text { diarrhea, and } \\
\text { weakness }\end{array}$ & 7 & $\begin{array}{l}\text { Dehydration } \\
\text { and } \\
\text { abdominal } \\
\text { tenderness }\end{array}$ & negative & non-reactive & $\begin{array}{c}+ \\
\text { (father) }\end{array}$ \\
\hline 4 & Female & 4 & - & $\begin{array}{l}\text { Fever, abdominal } \\
\text { pain, and diarrhea }\end{array}$ & 1 & $\begin{array}{l}\text { Dehydration } \\
\text { and toxicity }\end{array}$ & negative & non-reactive & $\begin{array}{c}+ \\
\text { (father) }\end{array}$ \\
\hline 5 & Male & 2.5 & Hypogammaglobulinemia & $\begin{array}{l}\text { Fever, vomiting, } \\
\text { diarrhea, and } \\
\text { headache }\end{array}$ & 2 & $\begin{array}{l}\text { Dehydration, } \\
\text { toxicity, and } \\
\text { abdominal } \\
\text { tenderness }\end{array}$ & negative & non-reactive & $\stackrel{+}{\text { (grandmother) }}$ \\
\hline
\end{tabular}


Table II: Laboratory tests and culture results of the patients.

\begin{tabular}{|c|c|c|c|c|c|}
\hline \multirow{2}{*}{ Laboratory tests } & \multicolumn{5}{|c|}{ Patients } \\
\hline & 1 & 2 & 3 & 4 & 5 \\
\hline WBC $\left(\times 10^{9} / \mathrm{L}\right)$ & 12.94 & 4.92 & 12.96 & 3.71 & 2.99 \\
\hline $\mathrm{Neu}(\times 10 \% / L)$ & 10.61 & 4.46 & 8.31 & 2.37 & 1.95 \\
\hline Lym (x10\%/L) & 0.6 & 1.19 & 2.6 & 1.02 & 0.63 \\
\hline $\mathrm{Hg}(\mathrm{g} / \mathrm{dL})$ & 13.5 & 11.5 & 12.6 & 11.5 & 11 \\
\hline Plt (x10\%/L) & 248 & 265 & 392 & 217 & 214 \\
\hline $\mathrm{CRP}(\mathrm{g} / \mathrm{dL})$ & 26 & 71 & 58 & 180 & 210 \\
\hline Procalcitonin ( $\mu \mathrm{g} / \mathrm{L})$ & 0.3 & 0.22 & 0.16 & 11.5 & 226.8 \\
\hline IL-6 (pg/mL) & 4.14 & 3.14 & 28.5 & 77.7 & 232 \\
\hline ESR $(\mathrm{mm} / \mathrm{h})$ & 9 & 15 & 83 & 32 & 86 \\
\hline Liver function tests & Elevated & Elevated & Elevated & Elevated & Elevated \\
\hline Kidney function tests & Normal & Affected & Normal & Normal & Affected \\
\hline Cardiac enzymes & Normal & Normal & Normal & Elevated & Elevated \\
\hline Coagulation tests & Normal & Normal & Normal & Prolonged & Prolonged \\
\hline D-dimer (mg/L) & 1.1 & 1.8 & 0.9 & 19.2 & 3 \\
\hline Ferritin $(\mu \mathrm{g} / \mathrm{L})$ & 25 & 29 & 226 & 511 & 239 \\
\hline $\begin{array}{l}\text { Microscopic } \\
\text { examination of stool }\end{array}$ & $\begin{array}{l}\text { Rare leukocytes } \\
\text { and 8-10 } \\
\text { erythrocyte/hpf }\end{array}$ & $\begin{array}{l}\text { Abundant } \\
\text { leukocytes/hpf }\end{array}$ & $\begin{array}{l}\text { 2-3 leukocytes and } \\
5-6 \text { erythrocytes/hpf }\end{array}$ & $\begin{array}{l}\text { Abundant leukocytes and } \\
8-10 \text { erythrocytes /hpf }\end{array}$ & $\begin{array}{l}\text { Abundant } \\
\text { leukocytes/hpf }\end{array}$ \\
\hline Stool culture & $\begin{array}{l}\text { Salmonella } \\
\text { enterica ssp } \\
\text { enterica }\end{array}$ & $\begin{array}{l}\text { Salmonella } \\
\text { enterica ssp } \\
\text { enterica }\end{array}$ & $\begin{array}{l}\text { Salmonella } \\
\text { enterica ssp } \\
\text { enterica }\end{array}$ & $\begin{array}{l}\text { Salmonella } \\
\text { enterica ssp } \\
\text { enterica }\end{array}$ & $\begin{array}{l}\text { Salmonella } \\
\text { enterica ssp } \\
\text { enterica }\end{array}$ \\
\hline Blood culture & Negative & Negative & Negative & $\begin{array}{l}\text { Salmonella } \\
\text { enterica ssp } \\
\text { enterica }\end{array}$ & $\begin{array}{l}\text { Salmonella } \\
\text { enterica ssp } \\
\text { enterica }\end{array}$ \\
\hline
\end{tabular}

CRP: C-reaktive protein (N: 0-5 g/dL), D-dimer (N: 0-0.55 mg/L), ESR: Erythrocyte sedimentation rate (N: 0-20 mm/h), Ferritin (N: 7-140 $\mu \mathrm{g} / \mathrm{L})$, Hg: Hemoglobin (N: 11.2-14.6 g/dL), IL-6: Interleukin 6 (N: 0-3.4 pg/mL), Lym: Lymphocyte (N: 1.5-6 x109/L), Neu: N0eutrophil (N: 1.5-8 x109/L), Procalcitonin (N: <0.16 $\mu \mathrm{g} / \mathrm{L})$, WBC: White blood cell (N: 4.8-12 x109/L).

a clear distinction could not be made for the patient's severe cardiac findings as to whether it was due to MIS-C or salmonellosis. However, the fact that the findings returned to normal in a short time with antibiotherapy was considered as salmonellosis-related cardiac involvement, and MIS-C diagnosis was excluded. Abdominal findings of patient 4 and 5 returned normal before discharge. While the source of transmission for Salmonella enterica ssp enterica was consumption of raw chicken and raw quail eggs in patient 4 and 5 , a clear source for bacterial contamination was not found in other patients. There were no symptoms suggestive of salmonellosis in any of the patients' family members.

\section{DISCUSSION}

Salmonellosis is a disease of global public health importance, and is directly related to water treatment, sewage disposal, animal exposures, and food-handling practices (9). Salmonella infections most often cause self-limiting gastroenteritis, but can also cause invasive infections with severe organ involvement that can result in morbidity or mortality $(9,10)$. Sepsis or sepsis-like conditions associated with invasive disease may not be attributed to Salmonella in the early period and may be confused with other conditions (10). Especially, enteric fever can mimic other infections of the reticuloendothelial system, or non-infectious illnesses such as collagen vascular diseases including juvenile rheumatoid arthritis and Kawasaki disease, and lymphomas (11). Similarly, Kawasaki syndrome and other vasculitis can be misdiagnosed as many infectious diseases (12). On this background of differential diagnosis challenge, MIS-C has emerged as an important cause of morbidity and mortality with the COVID-19 pandemic, and entered the world of pediatricians as a factor that causes serious confusion in diagnosis and treatment of many diseases.

MIS-C is a post-infectious event that occurs in individuals aged 0-21 years and causes symptoms a few weeks after infection with COVID-19 (1,2). Fever is a constant sign for MIS-C; cutaneous manifestations, abdominal symptoms and cardiovascular collapse are also common findings in most patients (13). Gastrointestinal manifestations including abdominal pain, diarrhea and vomiting are observed in 92\% of patients; may be severe enough to require surgery, and also 
Table III: Imaging records, supportive treatments, antibiotherapies and clinical outcomes, of the patients.

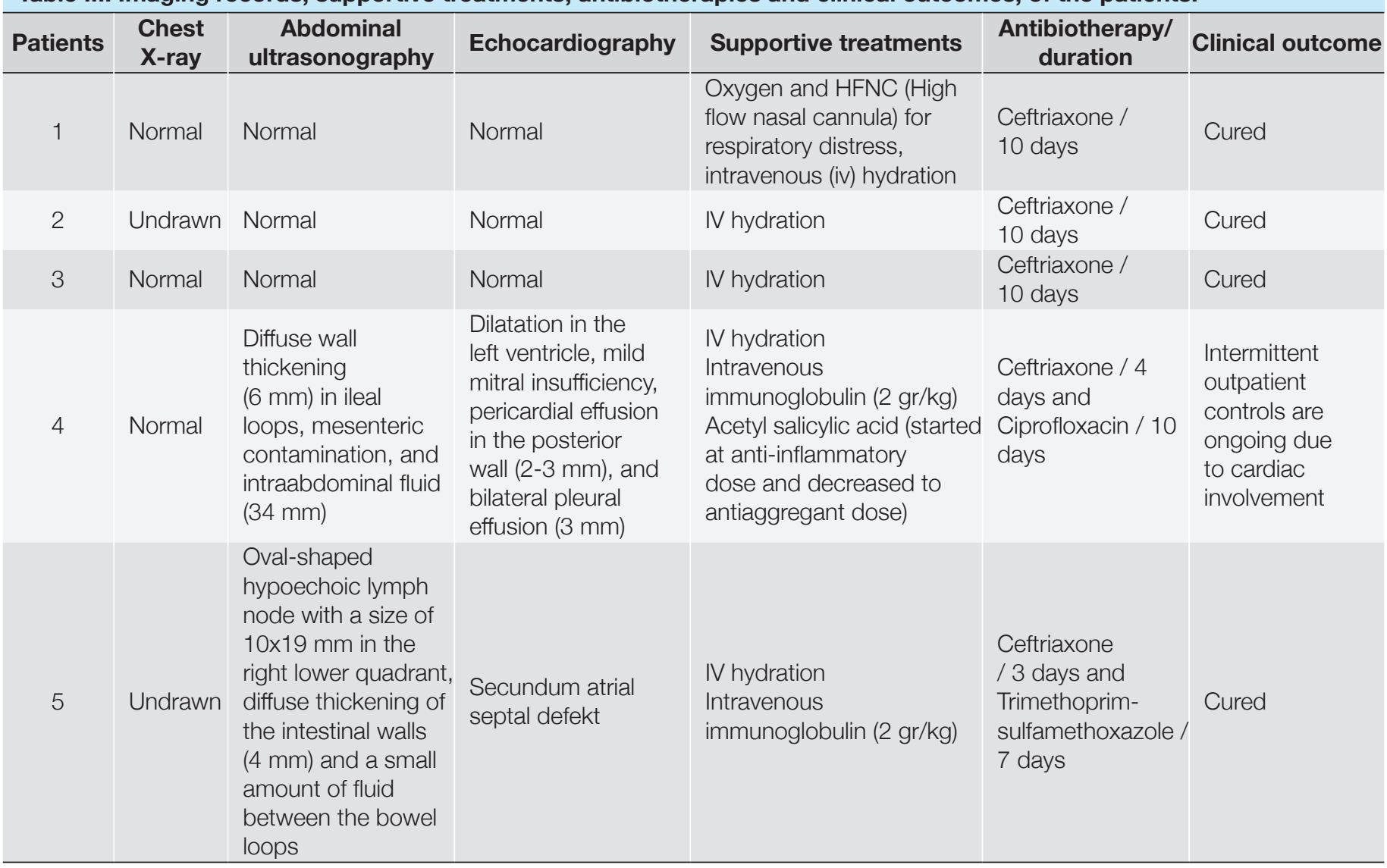

may be the only additional system findings accompanying fever $(13,14)$. Cardiac findings are detected in almost $80 \%$ of the patients, and half of the patients may progress to a severe shock-like condition requiring intensive care follow-up $(4,13)$. Due to increased cytokine responses and high inflammatory markers together with other system involvements, and high risk of morbidity and mortality, immediate intervention is essential without delay (5). The necessity of immediate intervention in this disease has revealed a new pediatric emergency, and prompted clinicians to rapidly initiate MIS-C treatment to prevent secondary complications in patients who have direct or indirect contact with COVID-19 and present with non-specific signs and symptoms suggestive of the syndrome. However, with this rapid intervention, possible infectious and non-infectious causes included in the differential diagnosis of MIS-C may be overlooked or delayed in diagnosis. There will even be cases that receive unnecessary treatment since there is no specific marker to make definitive diagnosis of MIS-C. For this reason, a careful analysis and careful examination of differential diagnosis is very important both during the patient's admission and during the follow-up. All of the patients in this case series presented with fever and significant gastrointestinal symptoms. In all of them, the significant elevations in inflammatory markers and strong evidence for infection or indirect contact with COVID-19 forced us to consider the diagnosis of MIS-C firstly. Some of the patients were even applied MIS-C initial treatments due to the deterioration of the general condition and toxic appearance on admission. Finally, stool and blood cultures obtained for possible infectious causes led us to a definitive diagnosis. To our knowledge, there is only one case report and one case series in the literature, that were considered a pre-diagnosis of MIS-C and were diagnosed with salmonellosis on follow-up $(15,16)$. There are also rare case reports of pediatric patients presented with findings indicative of MIS-C and were diagnosed with different infectious disease except for salmonellosis (17, 18).

Salmonella serotypes are designated based on the immunoreactivity of two cell surface structures, the $\mathrm{O}$ and $\mathrm{H}$ antigens, and serovars are identified beyond differentiating Salmonella isolates by subspecies level $(18,19)$. Clinically important Salmonella consist principally of a single species, Salmonella enterica, and S. enterica is further subdivided into six subspecies that are designated by taxonomic names: enterica, salamae, arizonae, diarizonae, houtenae and indica (17). The S. enterica subspecies covering more than 2500 serovars commonly encountered in clinical practice are grouped as typhoidal and non-typhoidal (11). Infection caused by Salmonella bacteria in the non-typhoidal group predominantly cause local intestinal inflammation, while those in the typhoidal group lead to systemic disease named as enteric (typhoid) fever $(11,13)$. 
These differences in the manifestations of infection by the 2 groups of pathogens brings about changes in the approach to infection and treatment plan (9-11). Among Salmonella infections, early diagnosis and treatment of typhoid fever with appropriate antimicrobials are essential (11). In Salmonella gastroenteritis other than typhoid fever, antimicrobial treatment do not have a clear indication (20). Because antibiotics do not shorten the course of illness and may prolong shedding of the organism in the stool $(20,21)$. There are also exceptions to the generalization that Salmonella gastroenteritis should not be treated; and also non-typhoidal Salmonella strains could cause disease mimicking enteric fever $(11,21)$. After all that mentioned, subtyping and serovar determination of Salmonella spp obtained in any culture is important. Unfortunately, serovar determination was not performed on isolates obtained from our patients, and we could not understand whether the patients had typhoid fever or invasive disease with non-typhoidal salmonella species. However, the use of raw animal products in patients 4 and 5 made us think that non-typhoidal serovars may be causative agents. The severity of clinical conditions and significantly elevations in inflammatory markers of the patients suggested invasive disease associated with Salmonella spp and antibiotherapy treatments were arranged accordingly. Salmonella enterica ssp enterica was observed in cultures of all patients, but since serotyping could not be performed, the antimicrobial treatments initiated were completed to the appropriate time for enteric fever or invasive non-typhoidal salmonellosis.

Varying degrees of AV blocks can occur for many reasons including infections and infection-associated myocarditis (22, 23). COVID-19-related cases and MIS-C patients with myocarditis have also been described $(24,25)$. Peri-myoendocarditis and arrhythmias are well known complications of Salmonella infections and have also been reported in children (26). Abnormal echocardiographic findings detected in patient 4 were interpreted as heart failure due to myopericarditis and secondary pleural effusion. Cardiac complications in this patient may have occurred due to both MIS-C and salmonellosis. However, the cardiac involvement was interpreted as releated to the infection more than MIS-C, since the findings did not gradually get worse and resolved spontaneously without additional treatment for MIS-C.

MIS-C overlaps with many other infectious and inflammatory diseases or syndromes that pediatricians often encounter in daily practice. Maintaining a proper clinical suspicion for other possibilities in the differential diagnosis is important in children presenting with clinical signs / symptoms suggestive of MIS-C and laboratory findings consistent with this syndrome. Appropriate index of suspicion is essential to not to miss the diagnosis of other possible infectious or non-infectious diseases and avoid over-treatment due to the possibility of MIS-C. This case series demonstrated the necessity of a careful treatment plan and a thorough review of other possible diagnoses in each step in children admitted with features suggestive of MIS-C along with severe elevations in inflammatory markers and strong evidences for COVID-19. Salmonella infections should be kept in mind as a causative agent of bacterial gastroenteritis in the differential diagnosis of patients with suspected MIS-C who present with increased cytokine levels accompanying fever and gastrointestinal system findings.

\section{REFERENCES}

1. Radia T, Williams N, Agrawal P, Harman K, Weale J, Cook J, et al. Multi-system inflammatory syndrome in children \& adolescents (MIS-C): A systematic review of clinical features and presentation. Paediatr Respir Rev 2021: 38:51-7.

2. Lee PY, Day-Lewis M, Henderson LA, Friedman KG, Lo J, Roberts JE, et al. Distinct clinical and immunological features of SARS-CoV2-induced multisystem inflammatory syndrome in children. J Clin Inves 2020;130:5942-50.

3. Consiglio CR, Cotugno N, Sardh F, Pou C, Amodio D, Rodriguez L, et al. CACTUS Study Team, Landegren N, Palma P, Brodin P. The Immunology of Multisystem Inflammatory Syndrome in Children with COVID-19. Cell 2020:183;968-81.

4. Aronoff SC, Hall A, Del Vecchio MT. The Natural History of SARS-Cov-2 Related Multisystem Inflammatory Syndrome in Children (MIS-C): A Systematic Review. J Pediatric Infect Dis Soc 2020:piaa112.

5. Dufort EM, Koumans EH, Chow EJ, Rosenthal EM, Muse A, Rowlands J, et al. New York State and CDC Multisystem Inflammatory Syndrome in Children Investigation Team. Multisystem inflammatory syndrome in children in New York State. N Engl J Med 2020;383:347-58.

6. Pereira F, Hsu D. Diarrhea. In: Shaw KN, Bachur RG (eds). Textbook of Pediatric Emergency Medicine. 7th ed. Wolters Kluwer: Philadelphia, PA 2016:35.

7. CDC. Multisystem inflammatory syndrome in children (MIS-C) associated with coronavirus disease 2019 (COVID-19). Accessed 8 July 2021. Available from: https://www.cdc.gov/coronavirus/2019ncov/daily-life-coping/children/mis-c.html.

8. WHO. Multisystem inflammatory syndrome in children and adolescents with COVID-19. Accessed 8 July 2021. Available from:https://www.who.int/publications/i/item/multisysteminflammatory-syndrome-in-childrenand-adolescents-with-covid-19.

9. Tack DM, Ray L, Griffin PM, Cieslak PR, Dunn J, Rissman T, et al. Preliminary Incidence and Trends of Infections with Pathogens Transmitted Commonly Through Food - Foodborne Diseases Active Surveillance Network, 10 U.S. Sites, 2016-2019. MMWR Morb Mortal Wkly Rep 2020;69:509-14.

10. Bhutta ZA. Typhoid fever: current concepts. Infect Dis Clin Pract 2006; 14:266-72.

11. Rife E, Gedalia A. Kawasaki Disease: an Update. Current Rheumatology Reports 2020;22:75.

12. Kabeerdoss J, Pilania RK, Karkhele R, Kumar TS, Danda D, Singh S. Severe COVID-19, multisystem inflammatory syndrome in children, and Kawasaki disease: immunological mechanisms, clinical manifestations and management. Rheumatol Int 2021;41:19-32.

13. Whittaker E, Bamford A, Kenny J, Kaforou M, Jones CE, Shah $\mathrm{P}$, et al. Clinical characteristics of 58 children with a pediatric 
inflammatory multisystem syndrome temporally associated with SARS-CoV-2. JAMA 2020;324:259-69.

14. Hoard JC, Medus C, Schleiss MR. A 3-Year-Old With Fever and Abdominal Pain: Availability Bias in the Time of COVID-19. Clin Pediatr (Phila) 2021;60:83-6.

15. Alamarat Z, Pérez N, Wootton S, Kamdar A, Smith K, Heresi GP, et al. Murine Typhus Outbreak Presenting as Multisystem Inflammatory Syndrome in Children During SARS-CoV-2 Pandemic. Pediatr Infect Dis J 2020;39:e447-9.

16. Dworsky ZD, Roberts JE, Son MBF, Tremoulet AH, Newburger JW, Burns JC. Mistaken MIS-C: A Case Series of Bacterial Enteritis Mimicking MIS-C. Pediatr Infect Dis J 2021;40:e159-61.

17. Repper DC, Arrieta AC, Cook JE, Renella P. A Case of Lemierre Syndrome in the Era of COVID-19: All That Glitters Is Not Gold. Pediatr Infect Dis J 2020;39:e445-7.

18. Brenner FW, Villar RG, Angulo FJ, Tauxe R, Swaminathan B. Salmonella nomenclature. J Clin Microbiol 2000;38:2465-7.

19. Agbaje M, Begum RH, Oyekunle MA, Ojo OE, Adenubi OT. Evolution of Salmonella nomenclature: a critical note. Folia Microbiol (Praha) 2011;56:497-503.
20. Nelson JD, Kusmiesz H, Jackson LH, Woodman E. Treatment of Salmonella gastroenteritis with ampicillin, amoxicillin, or placebo. Pediatrics 1980;65:1125-30.

21. Pettersson T, Klemola E, Wager O. Treatment of acute cases of Salmonella infection and Salmonella carriers with ampicillin and neomycin. Acta Med Scand 1964;175:185-90.

22. Batmaz G, Villain E, Bonnet D, L Iserin, A Fraisse, J Kachaner. Therapy and prognosis of infectious complete atrioventricular block in children. Arch Mal Coeur Vaiss 2000;93:553-7.

23. Kir D, Mohan C, Sancassani R. Heart Brake. An Unusual Cardiac Manifestation of COVID-19. JACC Case Rep 2020; 2:1252-5.

24. Dionne A, Mah DY, Son MBF, Lee PY, Henderson L, Baker AL, et al. Atrioventricular Block in Children With Multisystem Inflammatory Syndrome. Pediatrics 2020;146:e2020009704.

25. Huang DB, DuPont HL. Problem pathogens: extra-intestinal complications of Salmonella enterica serotype Typhi infection. Lancet Infect Dis 2005;5:341-8.

26. Azmatullah A, Qamar FN, Thaver D, Zaidi AK, Bhutta ZA. Systematic review of the global epidemiology, clinical and laboratory profile of enteric fever. J Glob Health 2015;5:20407. 